\title{
Design of an Off Grid Photovoltaic System for a Three Bedroom Flat in Makurdi, Benue State, Nigeria
}

\author{
Gbaakpen Msughter ${ }^{1}$, Mbakaan Celestine ${ }^{2}$ \\ ${ }^{1}$ Renewable Energy Engineering, Faculty of Science, Engineering and Computing, Kingston University, London \\ ${ }^{2}$ Department of Science Laboratory Technology, School of Technology, Benue State Polytechnic, Ugbokolo, Nigeria
}

\begin{abstract}
This is an off grid photovoltaic system designed for a three bedroom flat located in Makurdi Benue state, Nigeria. It is aimed at clearing doubts and fear engulfed by residential owners about photovoltaic systems in the country. The off grid photovoltaic system was design based on the electrical energy requirement of the flat. To achieve this, the power rating of common appliances which could be found in the flat were identified and multiplied by their time of operation to understand the energy demand of the house. The energy requirement of the flat was found to be $15.563 \mathrm{kwh}$ per day. The photovoltaic system was designed using Polysun application software. The result obtained from simulation shows that, the system will generate enough energy for operation of these appliances including in the night. The cost of the system was found to be $\$ 2862249$ with a lifetime of at least 20 years. The cost was compared with the use of fuel generator within the same period. The payback period was found to be approximately 2.72years. This means that the cost of photovoltaic system for the flat is high but after 2.7 years, the installer of the PV system will be using energy virtually free for the remainder of the lifetime of the system.
\end{abstract}

Keywords: Polysun, photovoltaic system, payback period, off grid

\section{Introduction}

The condition of energy generation and supply in Nigeria has deteriorated to the level that it is difficult to ascertain the time it will be available to consumers. Various administrations have come up with different ways of alleviating the situation but no meaningful result is achieved till date. Recently the country has privatized power sector but the expected result is still far reach [21]. Currently, the Nigeria electricity installed capacity is $8,876 \mathrm{MW}$ which is mostly from fossil fuels and still grossly inadequate to meet the energy needs of more than 160 million Nigerians [17]. The availability is far below the installed capacity due to many factors. In fact, the recent vandalism of gas pipelines that supply gas to power plants has caused power generation to drop to 1,580.6 megawatts in March, 2016 [16]. This has brought untold hardship on the citizens and derailed economics activities [7].

The installed capacity is not enough even when the power plants are generating at peak capacity. Only $40 \%$ of Nigeria's population is connected to the grid and the situation is worst in the rural areas. The distribution companies out of no other alternatives resolve to the used of rationing technique and mostly supplies electricity at very low current, but still those that have access to the grid; only $30 \%$ of their needs are met [1].

The inability of energy supply to match demand has become unacceptable to many citizens. As a result, they resort to other means of energy such as burning of wood and grasses, fuel or gas used generators, for domestic and day to day running of their business without considering the effects their energy sources might caused to the environment [11]. The electricity generates by Nigeria is mostly from fossil fuels which is the reason the country was in 2012, ranked $46^{\text {th }}$ in the world for $\mathrm{CO}_{2}$ emissions with more than 73.69 metric tons emitted in 2011 [2].

The introduction of photovoltaic technologies is a relief to the situation faced by Nigeria today. After all, the use of fossil fuel for energy generation is outdated due to its effects on climate. Apart from that, it is costly and mostly a source of conflict [22].

Photovoltaic is a technology used to convert sunlight directly to electricity. Photovoltaics are also called solar cells. When sunlight strike the surface of the cell, the energy from the light is enough to eject one electron from the shell of its host atom with a constant amount of energy. The electron removal is proportional to the intensity of micro packets of light energy usually referred to as photons [22]. Very close to the surface of the cell is a membrane called pn-junction which allows only electrons with a specific amount of energy to cross. This makes the surface of the cell facing the sun to acquire negative voltage while the other side is positive voltage [6]. If electrical cables are connected to the negative and positive sides, forming an electrical circuit, the electrons can be collected in the form of electric current (electricity) which can be used to power electric appliances. Figure 1 is the summary of how photovoltaic works. 


\section{International Journal of Science and Research (IJSR) \\ ISSN (Online): 2319-7064}

Index Copernicus Value (2013): 6.14 | Impact Factor (2015): 6.391

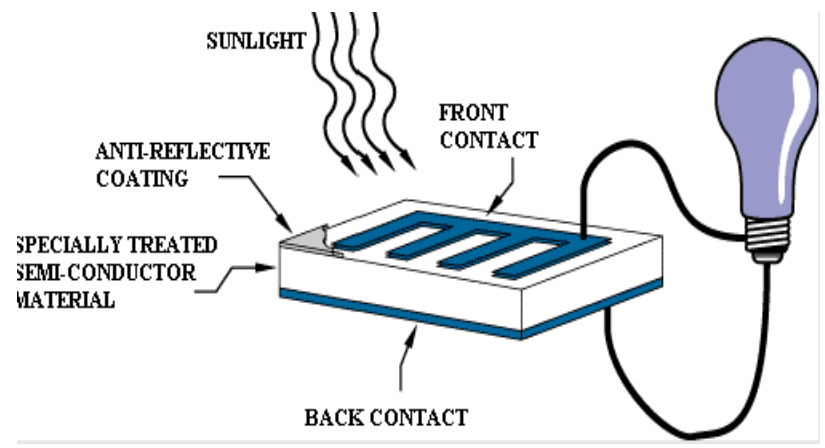

Source: [12]

Figure 1: How photovoltaic work

Different cells are connected together to form a solar module. A solar module supply electricity at a particular voltage just like conventional cells. Many different solar modules connected together forms an array. The solar module can have a life time of at least 20 years [12]. Photovoltaic is currently used in many countries for electricity generation. Figure 2 shows the global PV installation in 2016.

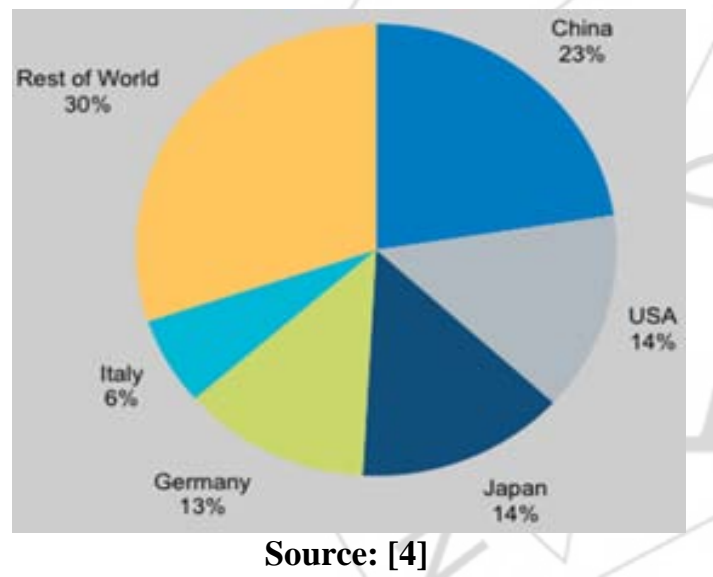

Figure 2: Global PV installation

Many researchers have found out that PV systems are cheap and will even get cheaper as time passes. The cost of a PV system includes the capital cost, operation and maintenance cost and installation cost. The cost depends on factors such as the size, and whether it is mounted on a roof top or on the ground [9]. The roof top PV does not require an extra space but mounting on the ground requires a separate space for the system. Figure 3 shows the projected price of photovoltaic modules.

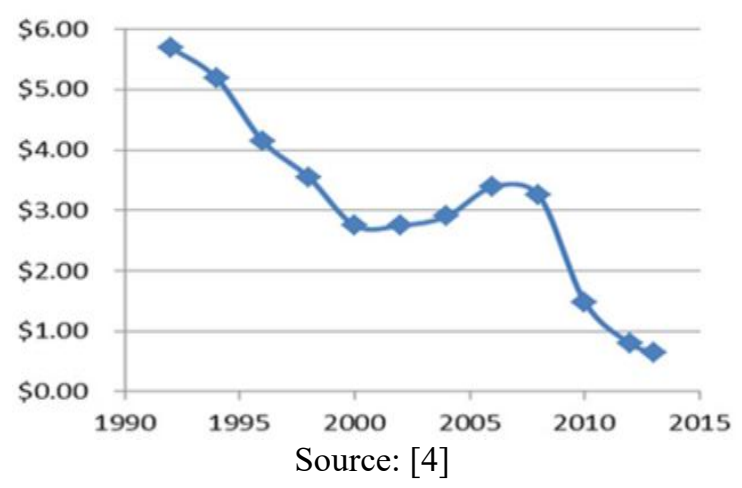

Figure 3: The decline in cost of PV modules

In a comparative study conducted by [10] at government secondary school Wudi, discovered that the cost of an off grid photovoltaic system is cheaper than the use of diesel for energy generation or when one embark on payment of electricity bills from the grid.

An off grid photovoltaic system generates electricity independently without grid connection. The components of the off grid photovoltaic system and their functions are seen in table 2 and the connection between the components is as seen in figure 4

Table 1: Components of PV system and their functions

\begin{tabular}{|c|c|}
\hline Component & Function \\
\hline Solar panel & $\begin{array}{l}\text { Collect solar energy from the sun and } \\
\text { convert it to electric current }\end{array}$ \\
\hline Battery & $\begin{array}{l}\text { Store electric power for later use when there } \\
\text { is no sun light }\end{array}$ \\
\hline Inverter & $\begin{array}{c}\text { It converts DC to AC for appliances that } \\
\text { uses AC }\end{array}$ \\
\hline Charge controller & Protect the battery from overcharging \\
\hline Electric meter & $\begin{array}{l}\text { Measures the electric current produced by } \\
\text { the solar panels }\end{array}$ \\
\hline Circuit breaker & $\begin{array}{l}\text { Prevent unwanted current from damaging } \\
\text { connect appliances }\end{array}$ \\
\hline Combiner box & $\begin{array}{l}\text { An electrical enclosure which is used to } \\
\text { connect different solar panels in parallel. }\end{array}$ \\
\hline & $\begin{array}{l}\text { This include wires, nuts, bolts, etc, for } \\
\text { conventional connections }\end{array}$ \\
\hline
\end{tabular}

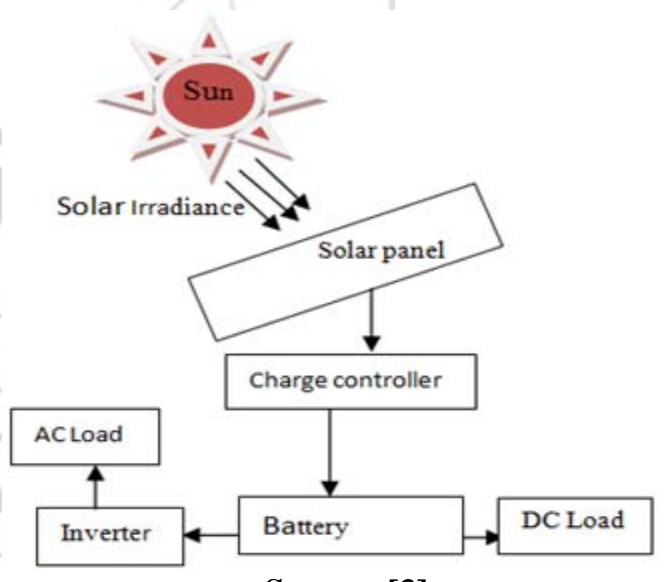

Source: [3]

Figure 4: Connection between PV components

\subsection{The location of the project and metrological data}

Makurdi is the capital of Benue state, Nigeria. It is located in the northern region of the country where solar energy is predominant. It is situated on latitude $7.719^{\circ}$ and longitude $8.545^{\circ}$. The solar irradiance incident on the location's site is as shown in figure 5 .

\begin{tabular}{cl}
\hline Average outdoor temperature & $26.9^{\circ} \mathrm{C}$ \\
Global irradiation, annual sum & $1.883 .4 \mathrm{kWh} / \mathrm{m}^{2}$ \\
Diffuse irradiation, annual sum & $950.5 \mathrm{kWh} / \mathrm{m}^{2}$ \\
Source: Polysun 1 &
\end{tabular}

Figure 5: Meteorological data of the Makurdi

\section{Volume 5 Issue 7, July 2016 www.ijsr.net}




\section{International Journal of Science and Research (IJSR) \\ ISSN (Online): 2319-7064}

Index Copernicus Value (2013): 6.14 | Impact Factor (2015): 6.391

\section{Methodology}

The common electrical loads which could be found in any average house were identified in conjunction with their power ratings. The time of operation of the loads was estimated based on their use, type and frequency. This was done in order to have a broad knowledge of the energy requirement of the house per day. The information obtained was used to designed the off grid residential PV system using Polysun application software.

\subsection{Estimated electricity consumption of the house}

The electric power consumption of the house appliances is calculated and tabulated as seen in table 3. Each of the appliance's power consumption was calculated separately to arrive at the total power consumption for the house.

Table 2: Daily energy demand of the flat

\begin{tabular}{|c|c|c|c|c|c|}
\hline Appliance & $\begin{array}{c}\text { Rated } \\
\text { power(w) }\end{array}$ & Number & $(\mathrm{KW})$ & $\begin{array}{c}\text { Hours } \\
\text { used/day }\end{array}$ & $\begin{array}{c}\mathrm{KWh} / \\
\text { day }\end{array}$ \\
\hline bulbs & 25 & 9 & 0.225 & 5 & 1.125 \\
\hline CD player & 35 & 1 & 0.035 & 6 & 0.21 \\
\hline 42' plasma TV & 250 & 1 & 0.25 & 6 & 1.50 \\
\hline Ceiling fan & 100 & 4 & 0.4 & 8 & 3.20 \\
\hline Iron & 1000 & 1 & 1.000 & & 1.00 \\
\hline Satellite dis & 30 & 1 & 0.03 & 8 & 0.24 \\
\hline Laptop & 25 & 3 & 0.075 & 8 & 0.60 \\
\hline fridge & 400 & 1 & 0.40 & 16 & 6.40 \\
\hline Cell phone & 4 & 5 & 0.02 & 3 & 0.06 \\
\hline Electric cattle & 150 & 1 & 0.15 & 1 & 0.15 \\
\hline Scanner & 18 & 1 & 0.018 & 1 & 0.018 \\
\hline Inkjet printer & 30 & 1 & 0.03 & 2 & 0.06 \\
\hline Washing machine & 500 & 1 & 0.50 & 2 & 1.00 \\
\hline total & & 30 & 3.133 & & 15.563 \\
\hline
\end{tabular}

\subsection{Selection of Photovoltaic Module}

The photovoltaic modules for the house were selected based on the voltage rating of the modules so that the system will be able to produce the daily energy requirement of the house. This was done with aid of Polysun application software. Table 4 shows the features of the selected PV module. The house will contain 24 modules. The tilt angle of the PV modules is $9^{0}$ closer to the latitude of the location.

Table 3: Features of the selected PV module

\begin{tabular}{|c|c|}
\hline Name & STP200S-18/Ud \\
\hline Manufacturer & Suntech power Co. Ltd \\
\hline Data source & Photon \\
\hline Number of modules & 24 \\
\hline Number of modules layout & 24 \\
\hline Total gross area & $46.57 \mathrm{~m}^{2}$ \\
\hline Tilt angle & $9^{0}$ \\
\hline orientation & 0 \\
\hline Total nominal generation field & $6.72 \mathrm{kw}$ \\
\hline Module type & monocrystalline \\
\hline Efficiency STC & 0.144 \\
\hline Nominal power STC & $280 \mathrm{w}$ \\
\hline Output voltage mpp-STC & $35.2 \mathrm{v}$ \\
\hline Output current mpp-STC & $7.95 \mathrm{~A}$ \\
\hline Open circuit voltage & $44.8 \mathrm{v}$ \\
\hline Open circuit current & $8.33 \mathrm{~A}$ \\
\hline Thickness & $0.05 \mathrm{~m}$ \\
\hline
\end{tabular}

\begin{tabular}{|c|c|}
\hline Length & $1.956 \mathrm{~m}$ \\
\hline Width & $0.992 \mathrm{~m}$ \\
\hline Gross area & $1.94 \mathrm{~m}^{2}$ \\
\hline
\end{tabular}

\section{4 selection of battery}

The off grid PV system for the house is designed such that it will not take power from the grid. Therefore provision has been made such that the occupants will have access to power even when sun might have set. The number of batteries required for the system is six (6). The simulation from Polysun application shows that these batteries will be enough to supply electric power to the house throughout the night. Table 5 is the name and features of the battery for the project.

Table 4: Features of the selected storage battery

\begin{tabular}{|c|c|}
\hline Name & $\begin{array}{c}\text { Hoppecke 24 } \\
\text { opzs3 3000 }\end{array}$ \\
\hline Nominal capacity & $6 \mathrm{kwh}$ \\
\hline Total nominal capacity & $36 \mathrm{kwh}$ \\
\hline Cumulative damage & $12 \%$ \\
\hline Lifetime & $5 \mathrm{years}$ \\
\hline Capacity ratio & 0.316 \\
\hline Minimum manufacture SOC (state of charge) & 0.3 \\
\hline Nominal voltage & $2 \mathrm{~V}$ \\
\hline Battery rate constant & 1.24 \\
\hline Charging efficiency & 0.927 \\
\hline Discharging efficiency & 0.927 \\
\hline Maximum charging power & $1220 \mathrm{w}$ \\
\hline Maximum discharging power & $3200 \mathrm{w}$ \\
\hline Daily safe discharge & 0.1 \\
\hline
\end{tabular}

\subsection{Selection of Inverter}

An inverter is an electronic device that converts dc current to ac current. The current produce by solar modules is dc current but most of the domestic appliances require ac current to power them. Therefore, an inverter is a necessity for an off grid PV system [5]. There are two types of inverters based on the form of wave they produced. They are called pure sine wave and modified sine wave. In this study, the pure sine wave inverter is preferred for its efficient performance and ability to operate any type of load. The selected inverter using Polysun application software is inverter $2900 \mathrm{~T}$ with $98 \%$ efficiency and $1 \%$ cable losses. Two inverters are required for the system.

\section{Energy Yield and Consumption}

After the design of the system and simulation using Polysun application software, the system will generate monthly energy as can be seen in figure 6. The energy generation is found to be highest in March and November. This means that, the solar irradiation on the location is highest in these months. Energy consumption is found to be highest in January and December. Figure 7 is the monthly consumption summary of the system. 


\section{International Journal of Science and Research (IJSR) \\ ISSN (Online): 2319-7064}

Index Copernicus Value (2013): 6.14 | Impact Factor (2015): 6.391

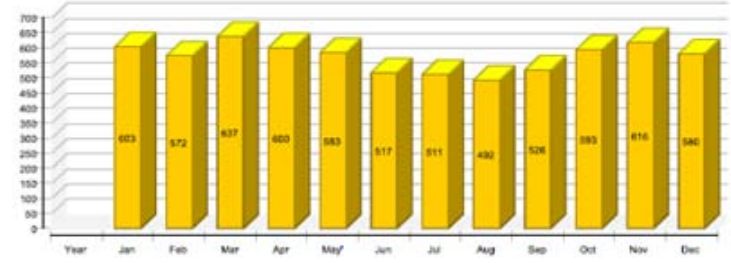

Source: Polysun 2

Figure 6: Energy yield of the designed system

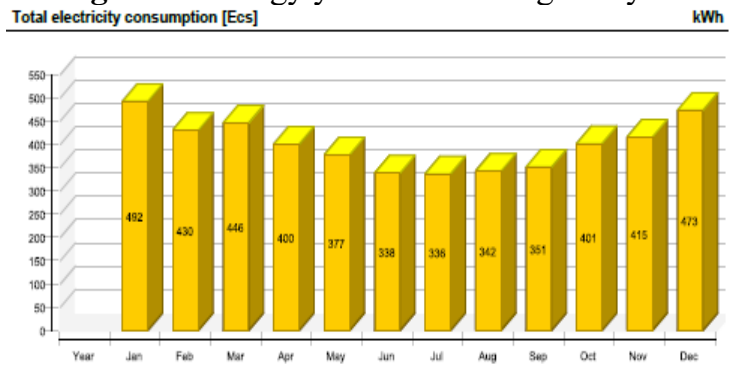

Source: Polysun 3

The off grid PV system will last for at least 20 years. Therefore, the maintenance cost for 20 years is the product of maintenance cost per year and years of its life time

Maintenance cost for 20 years $=\$ 2779 \times 20$

$=\$ 55560$

The cost of the system has been estimated based on economic realities but there is a need of contingency cost [22]. Contingency cost here means the cost that has not been accounted for in the course of cost estimation. Therefore the contingency cost is assumed to be $1 \%$ of the capital cost. That is:

Contingency cost $=1 \% \times 2778900$

$$
=\approx 27789
$$

The overall cost of the PV system for 20 years is the sum of capital cost, maintenance cost and contingency cost. That is: Overall cost $=2778900+55560+27789$

$$
=\mathrm{N} 2862249
$$

Figure 7: Energy consumption of the flat

\section{Cost estimation of the off grid PV system}

The cost of the residential PV system includes the total capital cost, installation cost, replacement cost, cost of operating and maintenance throughout the entire life of the system [15]. Generally, the capital cost of a solar system is very high but it has no fuel cost, the replacement cost of inverter and battery is low. Therefore, maintenance cost is low [13]. The cost estimation of the system is as seen in table 6 .

The life time of the system is 20 years. The life time of storage batteries is 5 years so it is expected that within the 20 year's life time, three extra sets of 6 batteries each will be bought. That is after five years, ten years and fifteen years. An extra inverter will be purchased after 12 years. All prices in table 5 are from [20].

Table 5: Capital cost estimation

\begin{tabular}{|c|c|c|c|c|}
\hline & & & & Years of specific p \\
\hline Component & Quantity & Price $(\mathbf{N})$ & 1 & 5 \\
\hline PV module & 24 & 80000 & 1920000 & $\$ 0900$ \\
\hline Battery & 6 & 15000 & $\$ 0000$ & \\
\hline Iimerter & 2 & 75000 & 150000 & \\
\hline Others componenets & & $10 \%$ of pv co & 192000 \\
\hline
\end{tabular}

The total cost per component $=$ quantity of the component $\mathrm{x}$ the unit price of the component. The cost of other components like fuses, meter, cables, etc is estimated to be $10 \%$ of PV cost.

PV systems require minimal maintenance because it has no fuel cost, no movable parts that may be damaged in the process [12]. Thus, maintenance cost of the system per year is estimated to be $0.1 \%$ of the system's capital cost.

Therefore Maintenance cost of the system per

$$
\begin{aligned}
\text { Year } & =0.1 \% \times 2778900 \\
& =\$ 2779
\end{aligned}
$$

\subsection{Cost Estimation of Fuel Generator}

Diesel generator will be used especially if there is no access to the grid. In this study, it is assumed that there is no grid connection and the user exclusively depends on the generator for energy generation for 20 years. All the cost stated in the study is obtained from [23]. The cost calculation for the fuel generator is as follows:

Sumec Firman ECO10990ES Petrol Generator 8.4KVA

$($ Key starter $)=\$ 195000$

Hours of use per day $=8$

Liters of fuel consumed per hour $=2$ Liters

Liters of fuel consumed per day $=2 \times 8$

$$
=16 \text { Liters }
$$

The total number of liters consumed per year

$$
\begin{aligned}
& =16 \times 365 \\
& =5840 \text { liters }
\end{aligned}
$$

The current price of fuel $=$ N140 per liter $[18]$

The cost of fuel per year $=140 \times 5840$

$$
=\$ 817600
$$

If the Maintenance cost of the generator per year is $10 \%$ of cost price, then

Maintenance cost $=0.1 \times 195000$

$$
=\$ 19500
$$

Cost of stabilizer 2000VA $=16000$

Cost of installation includes cost of wires, clips, etc. In this study, the installation cost is estimated to be $10 \%$ of the generator cost. That is:

Installation cost $=0.1 \times 195000$

$$
=\$ 19500
$$

The total cost of using the fuel generator is the sum of generator cost, fuel cost, stabilizer cost and cost of installation. That is:

Total cost of using fuel generator per year

$$
\begin{aligned}
& =195000+817600+19500+19500 \\
& =1051600
\end{aligned}
$$

The payback period from [19] can be calculated using this formula as

$$
\begin{gathered}
\begin{array}{c}
\text { payback period }(\boldsymbol{P b})= \\
\text { overall cost of pv systemfor } 20 \text { years }
\end{array} \\
\begin{array}{c}
\text { total cost of using fuel generator for the first year } \\
=\frac{2862249}{1051600}
\end{array}
\end{gathered}
$$




\section{International Journal of Science and Research (IJSR) \\ ISSN (Online): 2319-7064}

Index Copernicus Value (2013): 6.14 | Impact Factor (2015): 6.391

\section{$=2.72$ years}

This means that the user of the fuel generator will spend the same cost of off grid PV system after 2 years and seven months.

\section{Conclusion}

The study is the design of an off grid photovoltaic system for a three bedroom flat located in Makurdi, Benue state, Nigeria. This has become necessary because of inadequate electricity supply from the grid, the increase in militants' vandalism of pipelines that supply gas to electricity generating plants resulting to total black out or power shielding, arbitral charges from electricity distribution companies and the effects of $\mathrm{co}_{2}$ emission from fossil fuels. In the mist of these problems, photovoltaic system can use the abundant solar energy in Makurdi to generate electrical energy needed for daily use. This source is very cheap compare to the use of fuel generators as alternative energy source. Apart from that it is environmentally friendly; it brings about independent energy generation and economy stability.

The daily electrical need of the house was estimated using power rating of common domestic appliances and found to be $15.563 \mathrm{kw}$. The information was used to design a photovoltaic system for the house using Polysun application software. The system is made up of $24 \mathrm{PV}$ modules, 6 storage batteries, two inverters, charge controller and other electrical connecting devices. The simulation obtained shows that, the system will generate $6.72 \mathrm{kw} / \mathrm{h}$ which is enough to satisfy the energy requirement of the house. The PV system has a life time of 20 years. The estimated cost of the system is 2862249 which is very high but when it is compared with the use of fuel generator, the payback period was found to be approximately 2.72 years. This means that, after two years and seven months, the user of the PV system will be using energy from the system virtually free for the remainder of the system's life time.

\section{References}

[1] Abubakar, S.A., Ahmad, T. R. and Muneer, A. S, (2016). Nigeria electricity crisis: Power generation capacity expansion and environmental ramifications. Sciencedirect.com. Available at:http://www.sciencedirect.com/science/article/pii/S03 60544213007627 (Accessed: 01 June 2016)

[2] Adebayo, C. (2014) How is 100\% renewable energy possible for Nigeria? Available at: http://geni.org/globalenergy/research/renewable-energypotential-of-nigeria/100-percent-renewable-energyNigeria.pdf (Accessed: 18 May 2016)

[3] Anon, (2016). [Online] Available at: http:// www.solarwind.co.uk [Accessed 5 Jun. 2016].

[4] As European Solar Installations Slow, China, US and Japan Lead Global Installed PV Capacity in 2016, IHS Says | IHS Online Newsroom. (2016). Press.ihs.com. Available at:http://press.ihs.com/pressrelease/european-solar-installations-slow-china-us-andjapan-lead-global-installed-pvcapacity?newsletter $=$ photon + newsletter + + deutsche+ausgabe+vom+3.3.2016
[5] Assad A. (2010) A stand alone photovoltaic system, case study: A residence in Gaza', journal of applied science in environmental sanitation, $5, \mathrm{pp} .81-91$

[6] Blackers, A. (2013)' Explainer: what is photovoltaic solar energy?' Sahara Reporters, 26 March, 2013. Available at: http://theconversation.com/explainerwhat-is-photovoltaic-solar-energy-12924

[7] Emovon, A. I., Kareem, B. and Adeyeri, M.K. (no date) Power Generation in Nigeria: Problem and solution. $A$ vailable at: http://naee.org.ng/files/paper1.pdf (Accessed: 2 June 2016)

[8] Firman ECO10990ES Petrol Generator 8.4KVA (Key starter) (2016). Best Price on Konga. Available at: http:/www.konga.com/sumec-firman-firmaneco10990es-petrol-generator-8-4kva-key-starter2329564. (Accessed: 5 June 2016)

[9] IRENA (2012) Renewable Energy Technologies: Cost Analysis Series, (1) 5. Available at: https://www.irena.org/documentdownloads/publications $/$ re technologies_cost_analysis-wind_power.pdf (Accessed: 05 April 2016)

[10] Ishaq, M., Ibrahim, U.H. and Abubakar, H. (2013) 'Design of an off Grid Photovoltaic System: A Case Study of Government Technical College Wudil, Kano State', International Journal of Science and Technology Research 2 (12), PP.175-181

[11] Iwayemi, A. (2008) Nigeria's dual energy problems: Policy issues and challenges, International Association for energy economics, Fourth Quarter, 2008. Available at:

https://iaee.org/en/publications/newsletterdl.aspx?id=53 (Accessed: 20 March 2016)

[12] Knier, G. (2002) 'How Do Photovoltaics Work?' NASA Science. N.P.,2002. Available at: $\mathrm{http}: / /$ science.nasa.gov/science-news/science-atnasa/2002/solarcells/ (Accessed: 07 June 2016).

[13] Mirzaii, H. (2016) 'Solar Energy and Resources' AE7203: Solar Power Engineering. Available at: http://studyspace.kingston.ac.uk (Accessed: 13 May 2016).

[14] Nafeh, A. (2009). Design and Economic Analysis of a Stand-Alone PV System to Electrify a Remote Area Household in Egypt. The Open Renewable Energy Journal, 2(1), 33-37. Available at: http://dx.doi.org/10.2174/1876387100902010033

[15] Nixon, J. (2016) 'Economics of solar systems' AE7203: Solar Power Engineering. Available at: http://studyspace.kingston.ac.uk (Accessed: 29 April 2016).

[16] Okechukwu, N. \& Femi, A. (2016). Available at: $\mathrm{http}: / /$ theconversation.com/explainer-what-isphotovoltaic-solar-energy-12924. (2016).

[17] Oyedepo, S.O. (2012) Energy and sustainable development in Nigeria: the way forward. Energy, sustainability and society. Available at: http://energsustainsoc.springeropen.com/articles/10.118 6/2192-0567-2-15 (Accessed: 6 June 2016).

[18] SAHARA REPORTERS (2016) Nigerian Government deregulates downstream petroleum, raises price to 145 per liter. Available at: http://saharareporters.com/2016/05/11/nigeriangovernment-deregulates-downstream-petroleum-raisesprice-n145-liter 
[19] Sandia, (1995) stand - alone photovoltaic systems: A handbook of recommended design practices, Albuquerque New Mexico: Sandia national laboratories

[20]Solar World SW 285 Mono. (2016). Solarshopnigeria.com. Available at: http://www.solarshopnigeria.com/solarworld-sw285.html. (Accessed: 5 June 2016)

[21] Stein, C. (2016) Nigerian oil production falls as militants' attacks take toll. Voice of America. Available at http://www.voanews.com/author/24137.html (Accessed: 02 June 2016)

[22] Swift-Hook, D. (2016) 'Photovoltaics' AE7203: Solar Power Engineering. Available at: http://studyspace.kingston.ac.uk (Accessed: 10 May 2016).

[23] www.jumia.com.ng/catalog/?q=solar\%20charge $\% 20$ con troller\&utm_term $=8394 \% 20 \% 20$ Deeplink $\% 20$ Generato r\%20\%20ntg\&utm_campaign=10902\&utm_source=ing enious\&utm_medium=affiliation

Volume 5 Issue 7, July 2016 www.ijsr.net 